\title{
Industrialization: The Transition of the Community of Agrarists Toward the Gresik Wringinanom Industry
}

\author{
$1^{\text {st }}$ Kholifatus Saadah \\ Universitas Negeri Malang \\ Malang, Indonesia \\ fatussaadah@gmail.com \\ $2^{\text {nd }}$ Rista Anggraini \\ Universitas Negeri Malang \\ Malang, Indonesia
}

\author{
$3^{\text {rd }}$ Veneshia Auralia Medida \\ Universitas Negeri Malang \\ Malang, Indonesia
}

\author{
$4^{\text {th }}$ Agung Wiradimadja \\ Universitas Negeri Malang \\ Malang, Indonesia \\ agung.wiradimadja.fis@um.ac.id
}

\begin{abstract}
One of the roles of the industrial sector in economic development is to improve the quality of life by expanding employment that will improve the welfare of the community. Industrialization, in any process always brings change. After the existence of industry, the main profession of the people of Wringinom Sub-district was not farmers but shifted to other sectors such as industry, services, trade. A shift in the profession has also caused a shift in socioeconomic values. The purpose of this research is to find out the socio-economic changes in the Wringinom District after the establishment of the factory. This study uses descriptive qualitative, namely research that produces descriptive data in the form of written or oral words from people and actors observed in the field.
\end{abstract}

Keywords: industrialization, profession transformation, Wringinanom-Industry

\section{INTRODUCTION}

Industrialization is one of the long-term goals in fundamentally changing the economic structure from an initial focus on agricultural output [1]. The industrial world focuses the community on an economy that includes increasingly diverse jobs, processing raw materials into finished or semifinished goods, the use of advanced technology, faster work, and higher incomes. The development of the industrial sector has the role of expanding employment increasing quality of life, equitable development, increasing income and welfare of the community. Industrial development is carried out. The Provincial Government of East Java is concentrated in the Gerbangkertasusila region, including Gresik Regency. Industry has a role as (leading sector) meaning the leader sector [2]. The role of the industrial sector in the economic development in many countries is very important because it can play a key role as an engine of development, it is because the industry has a value of advantages compared to other sectors, namely the ability to create jobs are great, the ability to give value added to a product, and capitalization of capital which is very large.

Gresik Regency is determined as part of one of the Gerbangkertosusila development areas and also as an industrial area [3]. The success of industrialization by PT Petrokimia Gresik began in 1972, then had a huge influence on the changes in Gresik. After the entry of PT Petrokimia, it was able to attract investment in the industry so that a lot of new land was opened for industrial development. The establishment of PT Petrokimia marked Gresik as stepping into the era of industrialization. The presence of several industries in Gresik makes it a regency with great economic potential and experiencing rapid progress. The development of this large industrial estate is due to Gresik being considered as an area capable of supporting industrial activities well. Besides that, Gresik's strategic location is on the northern coast line, which is a Gerbangkertasusila region and close to the provincial capital. Have easy access to various infrastructure and means of land transportation. Therefore, the industrial sector plays an important role in economic growth.

The problems faced today are after industrialization, namely the readiness of the community in finding new jobs after environmental changes and socio-economic changes experienced after the industry. Industrialization in any process always brings change. The readiness of the local community must be fostered first in order to be ready to accept drastic circumstances both physically and mentally. Coaching is only 
possible with the presence of broad and deep knowledge, especially changes that occur in society. According to Supridjono's research said that as a result of the growth of industrial zones, changes in the structure of agrarian societies into industries that have an impact on changes in livelihoods, lifestyles, behavior, ways of thinking, and changes caused by the intervention of migrants. Industrialization is considered as a part of the modernization process that affects social and economic changes in a society.

\section{RESEARCH METHODS}

This study uses a qualitative descriptive approach, namely research that produces descriptive data in the form of written or oral words from the observed actors. Descriptive research is research that intends to make a description (description) of the situation or events. So its nature only describes and describes the findings obtained in the field. This study aims to describe and explain how the condition of society after industrialization.

Data retrieval and information acquired developed and containers back to fit the theme of research in doing. After that in associate information obtained in accordance with the situation on the ground. The instruments used in this study are interview guidelines and documentation in the form of primary secondary data.

\section{RESULTS AND DISCUSSION}

\section{A. Industrial Development in Wringinanom District}

Industrialization in Gresik indirectly affected the condition of Wringinom District. The development of industry in this region began around the 1990s. One of the factories that encourage industrial development here is PT Malindo Feedmil which is engaged in animal feed. Large industries that develop also affect industries that are emerging today. The existence of large industries gave rise to many medium and small industries. Starting from one factory to total 266 . The number of medium industries is 46, small 196 and large industries reach 24 in 2017 [3]. Industrial growth in this region is growing rapidly because it has easy accessibility to the capital of Surabaya, Gresik, Mojokerto. One of them is also close to Surabaya. Construction of the road network to remote villages has increased rapidly. The number of vehicles for the transportation of people and goods allows easy access for industrial development. This issue is considered as a way to open up employment opportunities.

The rapid development of the industry around 30 years has affected the conditions that exist in the District of Wringinom. Wringinom District has many industrial stands including textiles, steel, electronics, cartons, animal feed, paper, sandals. Practically this area stands many industries with small to medium scale and above. This provides a lot of jobs that are used by the surrounding community to cultivate them. This has become a trend of shifting the profession of farmers slowly.

\section{B. Adaptation of the Agricultural Sector to Changes to the Industrial Sector}

The conversion of agricultural land into factory buildings automatically changes the livelihoods of surrounding communities. If it was originally planted in the fields, then switched professions to become workers in the factory environment. This profession is generally occupied by people who have lower middle economic strata. The impact of the factory is also the presence of traders who hung at the edge of the factory. The livelihoods of the people before the industry were farmers, both farmers themselves and laborers. The agricultural system that is carried out is the rice farming system, but there are also a small part of which planted crops on dry land. The process of processing agricultural land is there that cultivates privately owned land, there are also those who cultivate land owned by other people with a production sharing system. The main occupation of the Wringinom District community today is as a factory worker. Based on BPS data in 2017 the industry can absorb labor by $38.79 \%$, while agriculture is $29.82 \%, 12 \%$ is in trade and its side is in the service sector, construction [3].

The industrialization in Wringinom received mixed responses from the community. For farmers to be a blessing because the land sells and the price is more expensive. There are also residents with the land purchased by the factory and then perform the pilgrimage. Some build houses after selling land and buying vehicles. Industrialization indirectly opens up new jobs thereby reducing unemployment. Community orientation is already open to the future so it is not difficult when going to switch jobs to industry. For traders as a new place of business to peddle merchandise. For the unemployed, it will be a job. Can open small industries. For the local government as a form of success attracting investors to participate in development.

The impact of the factory indirectly changes the existing profession. People start to have heterogeneous jobs, namely in the private sector such as traders, services, transportation, construction and others. However, the dominant profession is factory workers. On the other hand there are traders who have sprung up around the factory. Coffee shop traders or shops emerged after the factory. This is a form of real response from the community. In the midst of economic uncertainty experienced by society the creation of marginal groups is more due to the low level of education, which makes them unacceptable in the wheel of a modern economy. Maximum they can only be accepted in factories classified as rough labor.

The above description shows that farmers do not fully work as farmers as they used to. Wringinom sub-district is now half a village and half city. In the future residents will work in the commercial sector and will no longer be farmers. This is worth considering since now the main source of community income is no longer derived from agriculture. Especially if land 
ownership continues to move to people who have large capital. Economically, the presence of large industries is an important tool in improving the welfare of the population. Work as a factory worker is the main goal because it considers work in factory workers to have a higher income than working as a farmer. Industrial development has the aim of expanding employment, supporting equitable development, increasing income and welfare of the community [4].

Another reason revealed that the Wringinom Subdistrict community switched professions from agriculture, because so far agriculture has not been able to make a better contribution to their welfare. Production costs incurred are not proportional to the amount of income received from the harvest. The harvest time is also relatively long, while the cost of living must continue to be met. It is this condition that forms the basis for a large part of the shift in people's livelihoods. Working in a factory has an income of Rp.3,867,874 in 2019. While in previous years the salary earned was able to fulfill life. In fact, some people form an activity or business that supports the activities of the industry. For example opening a food stall. However, most people there choose to become workers in industries that are close to where they live. Jobs in the industry are prioritized rather than as farmers because the results of the permanent factory every month. Society began to transform from the characteristics of traditional society into modern society with a variety of work activities. This provides an opportunity for the community to do more, especially in the economic and service sectors.

Although the factory has a good impact on the economy. There are indirect effects that are starting to be felt. People are starting to adapt to the environment due to industrial impacts. People who used to consume ground water now turn to mineral water for drinking. That is because water is polluted with factory waste. the quality of the water has declined so that the community does not switch to bottled mineral water. The existence of industry there are positive things that can be felt by the community, namely: (1) can increase mediation by the existence of boarding houses; (2) increase the income of the community around the industry (3) can work part-time besides working in a factory, especially for housewives who come from local residents.

\section{Industrial Influence in Changing Socio-Economic Life}

The influence of the environment, the community tries to adjust to environmental conditions by changing activities in accordance with existing conditions to seize economic opportunities. The impact of the factory is also the presence of traders who hung at the edge of the factory, especially near the gate. Working in a factory not only promotes economic growth, but also impacts on people's social lives.

Economic changes cause social changes such as population growth due to the arrival of residents who work in factories, there is a pattern of community economic shifts that cause shifts in lifestyle. The problem that often occurs is the change in employment of most people, especially those living in rural areas. Initially working as a farm laborer became a factory worker [5][6]. This also happens in the community that the community switches to industrial and other economic systems such as trade. The presence of industry in the community certainly brings an impact. Livelihoods change is able to change the social order that exists in society along with the increasingly heterogeneous livelihoods. These livelihood changes are usually accompanied by socioeconomic changes in the culprit. There are changes in the family system that exists in industrial societies [4]. Long before the existence of industry, society upheld harmony among fellow citizens, so after the entry of the industry experienced a slight shift. The existing family system is a bit stretched. Mutual cooperation and a sense of help to be tenuous. The pattern of family care also experiences differences with the farming community because parents do not have free time as in the culture of farmers.

Industrial societies will tend to be more individualistic and consumptive due to industrialization [4][7]. Significant economic changes make society tend to be more consumptive. This is indeed the case in the Wringinom community, where people who work in factories are more economically secure than those who only work in agriculture. Jobs in the industry are prioritized rather than as farmers because the results of the permanent factory every month. From an economic perspective, success will certainly cause very significant changes in the economic structure of society. In the social sector, it is estimated that industrialization will cause a social structure where most of the community members will depend on their livelihoods in the industrial sector [3][8]. The industry will affect the social life of the community directly and indirectly.

\section{CONCLUSION}

Industrialization can affect the socio-economic life of the community. one of the goals of industrialization is public welfare. One of the factors driving industrialization in Wringinom is very easy accessibility. Industrialization opens up new jobs thereby reducing unemployment. The influence of industry in society can cause socio-economic changes. These changes such as changes in land ownership and use, changes in the profession and changes in people's income. The existing family system is a bit stretched. Mutual cooperation and taste please start to wear off. Industry has an influence on socioeconomic changes.

\section{REFERENCES}

[1] Supridjono, Agus, Maghfiroh Nurul. 2018. Dampak Industri Pt Petrokimia Gresik Terhadap Kehidupan Sosio-Kultural Masyarakat 
[6] Ismanto, K; H.M. Huda; C. M. 2012. Transformasi Masyarakat Petani Mranggen Menuju Masyarakat Industri. Jurnal Penelitian. Volume 9(1): $35-48$.

[7] Rahmawati FK, Setyono JS. 2014. Perkembangan industri di pedesaan dan perubahan karakteristik wilayah desa di Desa Nguwet Kecamatan Kranggan Kabupaten Temanggung. Jurnal Teknik PWK. Vol. 3 (4): 792-806.

[8] Yogiana, Made. 2013. Pengaruh Pembangunan Industri Terhadap Kondisi Sosial Ekonomi Petani Tambak di Kecamatan Manyar Kabupaten Gresik. 83-90

[5] Sutisna. 2008. Perilaku konsumen dan komunikasi pemasaran. Bandung: PT. Remaja Rosdakarya. 